[Bull. Agr. Chem. Soc. Japan, Vol. 21, No. 4, p. 230 234, 1957]

\title{
Studies on the Influence of Different Algerian Rock Phosphates when Reinforced with Leguminous Plant Material Like Cow-Pea (Vigna-Sinensis) on Carbon Transformations, Exchangeable Calcium and $\mathrm{pH}$ of the Alkali Soil
}

\author{
By S.P. Mitra and Hari Shanker \\ Shila Dhar Institule of Soil Science, University of Allahabad, Allahabad, India.
}

Received October 4, 1956

The importance of phosphates is due to the reason that phosphorous is an essential constituent of plant and animal life; the quantity in the average soil is relatively small, particularly in alkali soil, and there is no atmospheric supply of this element on which plants can grow. It is seldom that crop fails to respond with increased yields when soluble phosphates are applied to soils that have been under cultivation for 25 years or more. Collings' has stated as follows:-

"Low crop yields are more often due to the lack of phosphoric acid than due to the lack of any other nutrient. Phosphoric acid has often been called the 'master key' to agriculture. Phosphoric acid appears to be concerned in the production of nucleo-proteids, and it appears that phosphoric acid influences the production of seeds or grain more particularly than does nitrogen or potash".

It is well known that when water-soluble phosphates are added to the soil, a major part is rapidly converted into insoluble form, i.e., fixed by the soils and only a small portion of the added phosphate is taken up by the plants. Soils vary greatly in their capacity to fix phosphates. The organic matter, the $\mathrm{pH}$, the amount of soluble calcium and magnesium, the amount and chemical nature of the clay colloids and the amount of iron and alumi1) G.H. Collings, Commercial Fertilizers, p. 393-94 (1954);
McGraw Hill Book Company.

2) E.J. Russell, Soil Conditions and Plant Growth. p. 457, 1950 Edition, Longmans. nium present in the soils are all important factors affecting the phoshate fixing power of the soils and the nature of the compound formed. According to Russel2), in neutral and alkaline soils, the dicalcium phosphate appears to react with more calcium, giving perhaps first a compound of the octa-phosphate type $\mathrm{Ca}_{4} \mathrm{H}\left(\mathrm{PO}_{4}\right)_{3}$ before reverting to an apatite $\mathrm{CaX}_{2}, \mathrm{Ca}_{3}\left(\mathrm{PO}_{4}\right)_{2}$ where $\mathrm{X}=\mathrm{OH}$ or $\mathrm{F}$.

The present studies were undertaken by us to see the effect of decomposing organic matter on the increased availability of phosphates added and the beneficial effect of the solubilized phosphates on the $\mathrm{pH}$ value of the alkali soil together with an increase in the availability of phosphate and exchangeability of calcium.

\section{METHODS AND MATERIALS}

Total carbon was estimated by the Robinson, McLeans and Williams ${ }^{3}$ method. Exchangeable calcium was determined by the $\mathrm{NaCl}$ method of Hissinik ${ }^{4}$. Available phosphate was determined by the 2\% citric acid method of Dyer ${ }^{5)}$; the $\mathrm{pH}$ was determined by a Beckman pH-meter.

The soil used in the experiments was collected from "Community Project Area", Phulpur Allahabad (India) and from Soraon, Allahabad, (India). Five samples of Algerian rock phosphates were obtained

3) G.W., Robinson, W. McLeans, and R. Williams, The Deteminations of Organic Carbon in Soils: J. Agri. S:i., 29, 315 (1929)

4) D.J. Hissink, Method for Estimating Adsorbed Bases in Soils and the Importance of these Bases in Soils : Soil Sci., 15, 269-76 (1923).

5) B. Dyer, On the Analycical Determination of Probably Available 'Mineral' Plant Food in Soils: Trats. Cbem. Soc, 65, 115-167 (1894). 
from France. The leguminous plants (cow-pea) were brought from the Agricultural Institute, Naini, Allahabad (India).

Two handred grams of well-powdered alkali soil, after being passed through a 80 mesh sieve, were taken in shallow enamelled dishes. To these soils $1.0 \%$ carbon in one set of Phulpur soil and Soraon soil and $0.5 \%$ carbon only in Phulpur soil in another set were added in the form of cow-pea (Vigna-sinensis). To these sets $0.25 \% \mathrm{P}_{2} \mathrm{O}_{5}$ in the form of the five Algerian rock phosphates, named, respectively $A, B$, $C, D_{1}$ and $D_{2}$ were added. The contents of the dishes were taken in a pestle and mortar and mixed thoroughly to make a homogeneous mixture. About $20 \%$ of distilled water was added to each dish. These dishes were exposed to the light of 500 Watt electric bulb hung at a distance of nearly two feet. The contents of the dishes were stirred on alternate days to facilitate acration and about $20 \%$ of water was added on alternate days. Composite samples were taken and analysed for total carbon, exchangeable calcium, available phosphate and $\mathrm{pH}$, respectively.

\section{RESULTS}

TABLE I

Analysis of Algerian Rock Phosphates FOR TOTAL $\mathrm{P}_{3} \mathrm{O}_{5}$ AND AVAILABLE $\mathrm{P}_{2} \mathrm{O}_{9}$ Phosphate

Total $\mathrm{P}_{2} \mathrm{O}_{5} \%$ Available $\mathrm{P}_{2} \mathrm{O}_{5}$ \%

$\begin{array}{lll}\mathrm{A} & 29.62 & 7.57 \\ \mathrm{~B} & 26.45 & 5.62 \\ \mathrm{C} & 33.37 & 6.64 \\ \mathrm{D}_{1} & 39.58 & 3.01 \\ \mathrm{D}_{2} & 39.78 & 3.09\end{array}$

TABLEA II

Percentage Chemical Composition OF THE SOILS USED

Phulpur soil Soraon soil

1. Moisture

$\begin{array}{ll}1.3 & 1.7 \\ 3.2 & 1.9 \\ 84.19 & 82.10 \\ 7.05 & 9.85 \\ 4.03 & 1.68 \\ 1.20 & 1.12 \\ 1.30 & 1.73 \\ 0.11 & 0.13 \\ 0.017 & 0.016 \\ 0.23 & 0.11 \\ 0.04 & 0.03 \\ 4.5 \text { m.e.\% } & 3.8 \text { m.e.\% }\end{array}$

2. Loss on ignition

3. HCl insoluble

4. Sesquioxide

5. $\mathrm{Fe}_{2} \mathrm{O}_{3}$

6. $\mathrm{CaO}$

7. $\mathrm{MgO}$

8. $\mathrm{P}_{2} \mathrm{O}_{5}$ (total)

9. Available $\mathrm{P}_{2} \mathrm{O}$

10. Total carbon

12. Exchangeable Ca Algerian Rock

\section{Experiments with Soraon alkali soil}

Average temperature $-30^{\circ} \mathrm{C}$

TABLE III

$200 \mathrm{~g}$ soil $+1 \%$ ó $\mathrm{C}$ as Cow-pea $+0.25 \% \mathrm{P}_{2} \mathrm{O}_{5}$ as Algerian Rock Phosphate (A).

Period of Total Carbon Availa- Ex. Ca. exposure Carbon oxidized ble $\mathrm{P}_{2} \mathrm{O}_{5}$ in m.e. pH in days $\%$ \% $\%$ \%

$\begin{array}{llllll}0 & 1.11 & - & 0.036 & 3.9 & 10.3\end{array}$

$\begin{array}{lllllr}80 & 0.72 & 0.40 & 0.049 & 5.3 & 9.4\end{array}$

$\begin{array}{llllll}160 & 0.63 & 0.49 & 0.070 & 6.2 & 8.5\end{array}$

$\begin{array}{llllll}270 & 0.48 & 0.63 & 0.076 & 6.7 & 7.4\end{array}$

TABLE IV

$200 \mathrm{~g}$ soil $+10 \% \mathrm{C}$ as Cow-pea+0.25\% $\mathrm{P}_{2} \mathrm{O}_{5}$ as Algerian Rock Phosphate (B)

Period of Total Carbon Availa- Ex. Ca. exposure Carbon oxidized ble $\mathrm{P}_{2} \mathrm{O}_{5}$ in m.e. pH

\begin{tabular}{|c|c|c|c|c|c|}
\hline days &, 0 & 10 & 00 & 0 & \\
\hline 0 & 1.11 & $\ldots$ & 0.028 & 3.8 & 10.3 \\
\hline 80 & 0.73 & 0.38 & 0.039 & 5.1 & 9.6 \\
\hline 160 & 0.65 & 0.47 & 0.064 & 6.0 & 8.6 \\
\hline 270 & 0.49 & 0.62 & 0.07 & 6.6 & 7.6 \\
\hline
\end{tabular}

TABLE V

$200 \mathrm{~g}$ soil $+1 \%$ G as Cow-pea $+0.25 \% \mathrm{P}_{2} \mathrm{O}_{5}$ as Algerian Rock Phosphate (C)

Period of Total Carbon Availa- Ex. Ca. exposure Carbon oxidized ble $\mathrm{P}_{2} \mathrm{O}_{5}$ in m.c. $\mathrm{pH}$ in days

$\begin{array}{rrrrrr}\text { days } & 0 & 0 & 0 & 0 & \\ 0 & 1.11 & - & 0.003 & 3.8 & 10.3 \\ 80 & 0.73 & 0.39 & 0.042 & 5.2 & 9.4 \\ 160 & 0.64 & 0.48 & 0.067 & 5.8 & 8.6 \\ 270 & 0.49 & 0.62 & 0.072 & 6.6 & 7.5\end{array}$

11. Total nitrogen

\section{TABLE VI}

$200 \mathrm{~g}$ soil $+1 \% \mathrm{C}$ as Cow-pea+0.25\% $\mathrm{P}_{2} \mathrm{O}_{5}$ as Algerian Rock Phosphate $\left(D_{1}\right)$

Period of Total Carbon Availa- Ex. Ca. exposure Carbon oxidized ble $\mathrm{P}_{2} \mathrm{O}_{5}$ in m.e. $\mathrm{pH}$ in days of $\%$ ó

TABLE VII

$200 \mathrm{~g}$ soil $+1 \% \mathrm{C}$ as Cow-pea $+0.25 \% \mathrm{P}_{2} \mathrm{O}_{5}$ as Algerian Rock Phosphate $\left(D_{2}\right)$

Period of Total Carbon Availa- Ex. Ca. exposure Carbon oxidized ble $\mathrm{P}_{2} \mathrm{O}_{5}$ in m.e. $\mathrm{pH}$

$\begin{array}{rrrrrr}0 & 1.11 & - & 0.025 & 3.8 & 10.3 \\ 80 & 0.74 & 0.38 & 0.038 & 5.2 & 9.5 \\ 160 & 0.65 & 0.46 & 0.062 & 5.9 & 8.7 \\ 270 & 0.50 & 0.61 & 0.064 & 6.5 & 7.7\end{array}$

$\begin{array}{rrrrrr}0 & 1.11 & - & 0.024 & 3.8 & 10.3 \\ 80 & 0.74 & 0.37 & 0.033 & 5.0 & 9.6 \\ 160 & 0.65 & 0.46 & 0.059 & 5.9 & 8.6 \\ 270 & 0.50 & 0.62 & 0.064 & 6.6 & 7.6\end{array}$
in days ó \% $\%$ ó 
Experiments with Phulpur Alkali soil

Average temperature- $-30^{\circ} \mathrm{C}$

TABLE VIII

$200 \mathrm{~g}$ soil $+1 \% \mathrm{C}$ as Cow-pea $+0.25 \% \mathrm{P}_{2} \mathrm{O}_{5}$ as Algerian Rock Phosphate (A)

$\begin{array}{cccccc}\begin{array}{c}\text { Period of } \\ \text { exposure }\end{array} & \begin{array}{c}\text { Total } \\ \text { Carbon }\end{array} & \begin{array}{c}\text { Carbon } \\ \text { oxidized }\end{array} & \begin{array}{c}\text { Availa- } \\ \text { ble } \mathrm{P}_{2} \mathrm{O}_{5}\end{array} & \begin{array}{c}\text { Ex. Ca. } \\ \text { in m.e. }\end{array} & \begin{array}{c}\text { pH } \\ \%\end{array} \\ 0 & 1.23 & \% & -6 & \% & \\ 60 & 0.78 & 0.45 & 0.051 & 6.2 & 8.8 \\ 120 & 0.68 & 0.55 & 0.069 & 6.9 & 7.7\end{array}$

TABLE IX

$200 \mathrm{~g}$ soil $+1 \% \mathrm{C}$ as Cow-pea $+0.25 \% \mathrm{P}_{2} \mathrm{O}_{5}$ as Algerian Rock Phosphate (B)

\begin{tabular}{|c|c|c|c|c|c|}
\hline $\begin{array}{l}\text { Period of } \\
\text { exposure } \\
\text { in days }\end{array}$ & $\begin{array}{c}\text { Total } \\
\text { Carbon } \\
\%\end{array}$ & $\begin{array}{c}\text { Carbon } \\
\text { oxidized } \\
\text { \%ó }\end{array}$ & $\begin{array}{l}\text { Availa- } \\
\text { ble } \mathrm{P}_{2} \mathrm{O}_{5} \\
\% \frac{1}{3}\end{array}$ & $\begin{array}{l}\text { Ex. Ca. } \\
\text { in m.e. } \\
\text { \%o }\end{array}$ & $\mathrm{pH}$ \\
\hline 0 & 1.23 & - & 0.028 & 4.6 & 9.7 \\
\hline 60 & 0.78 & 0.46 & 0.040 & 5.4 & 9.1 \\
\hline 120 & 0.72 & 0,51 & 0.060 & 6.0 & 7.9 \\
\hline
\end{tabular}

TABLE X

$200 \mathrm{~g}$ soil $+1 \% \mathrm{C}$ as Cow-pea $+0.25 \% \mathrm{P}_{2} \mathrm{O}_{5}$ as Algerian Rock Phosphate (C)

Period of Total Carbon Availa- Ex. Ca. exposure Carbon oxidized ble $\mathrm{P}_{2} \mathrm{O}_{5}$ in m.e. pH

$\begin{array}{rrrrrr}0 & 1.23 & - & 0.034 & 4.6 & 9.7 \\ 60 & 0.79 & 0.44 & 0.043 & 5.7 & 8.6 \\ 120 & 0.71 & 0.52 & 0.067 & 6.5 & 7.8\end{array}$

TABLE XI

$200 \mathrm{~g}$ soil $+1 \% \mathrm{C}$ as Cow-pea+0.25\% $\mathrm{P}_{2} \mathrm{O}_{5}$ as Algerian Rock Phosphate $\left(\mathrm{D}_{1}\right)$

Period of Total Carbon Availa- Ex. Ca. exposure Carbon oxidized ble $\mathrm{P}_{2} \mathrm{O}_{5}$ in m.e. $\mathrm{pH}$ in days

0

1.23 $\%$ \% $\%$

$60 \quad 0.87$

0.37

0.025

4.6

$5.6-8.8$

120

0.73

0.50

0.060

6.2

TABLE XII

$200 \mathrm{~g}$ soil $+1 \% \mathrm{C}$ as Cow-pea $+0.25 \% \mathrm{P}_{2} \mathrm{O}_{5}$ as Algerian Rock Phosphate $\left(\mathrm{D}_{2}\right)$

Period of Total Carbon Availa- Ex. Ca. exposure Carbon oxidized ble $\mathrm{P}_{2} \mathrm{O}_{5}$ in m.e. pH in days $\% \circ \%$

$\begin{array}{rrrrrr}0 & 1.23 & - & 0.026 & 4.6 & 9.6 \\ 60 & 0.83 & 0.40 & 0.038 & 5.5 & 8.8 \\ 120 & 0.71 & 0.52 & 0.063 & 6.2 & 7.7\end{array}$

TABLE XIII

$200 \mathrm{~g}$ soil $+0.5 \% \mathrm{C}$ as Cow-pea $+0.25 \% \mathrm{P}_{2} \mathrm{O}_{5}$ as Algerian Rock Phosphate (A)

Period of Total Carbon Availa- Ex. Ca. exposure Carbon oxidized ble $\mathrm{P}_{2} \mathrm{O}_{5}$ in m.e. pH in days \% \% \% \%

$\begin{array}{llllll}0 & 0.83 & - & 0.036 & 4.6 & 9.6\end{array}$

$\begin{array}{llllll}60 & 0.56 & 0.27 & 0.048 & 5.3 & 8.6\end{array}$

$\begin{array}{llllll}120 & 0.45 & 0.38 & 0.070 & 6.0 & 7.8\end{array}$

\section{TABLE XIV}

$200 \mathrm{~g}$ soil $+0.5 \% \mathrm{G}$ as Cow-pea $+0.25 \% \mathrm{P}_{2} \mathrm{O}_{5}$ as Algerian Rock Phosphate (B)

\begin{tabular}{|c|c|c|c|c|c|}
\hline $\begin{array}{l}\text { Period of } \\
\text { exposure } \\
\text { in days }\end{array}$ & $\begin{array}{c}\text { Total } \\
\text { Carbon } \\
\%\end{array}$ & $\begin{array}{c}\text { Carbon } \\
\text { oxidized } \\
\%\end{array}$ & $\begin{array}{c}\text { Availa- } \\
\text { ble } \mathrm{P}_{2} \mathrm{O}_{5} \\
\%\end{array}$ & $\begin{array}{l}\text { Ex. Ca. } \\
\text { in m.e. } \\
\% \%\end{array}$ & $\mathrm{pH}$ \\
\hline 0 & 0.83 & - & 0.028 & 4.6 & 9.6 \\
\hline 60 & 0.51 & 0.32 & 0.041 & 5.4 & 8.8 \\
\hline 120 & 0.45 & 0.38 & 0.058 & 6.0 & 7.9 \\
\hline
\end{tabular}

TABLE XV

$200 \mathrm{~g}$ soil $+0.5 \% \mathrm{C}$ as Cow-pea+0.25\% $\mathrm{P}_{2} \mathrm{O}_{5}$ as Algerian Rock Phosphate (C)

Period of Total Carbon Availa- Ex. Ca. exposure Carbon oxidized ble $\mathrm{P}_{2} \mathrm{O}_{5}$ in m.e. pH in days $\%$ \% $\%$

$\begin{array}{rrrrrr}0 & 0.83 & - & 0.034 & 4.6 & 9.6 \\ 60 & 0.53 & 0.30 & 0.040 & 5.5 & 8.8 \\ 120 & 0.47 & 0.36 & 0.060 & 6.1 & 7.8\end{array}$

\section{TABLE XVI}

$200 \mathrm{~g}$ soil $+0.5 \% \mathrm{G}$ as Cow-pea $+0.25 \% \mathrm{P}_{2} \mathrm{O}_{5}$ as Algerian Rock Phosphate $\left(\mathrm{D}_{2}\right)$

Period of Total Carbon Availa- Ex. Ca. exposure Carbon oxidized ble $\mathrm{P}_{2} \mathrm{O}_{5}$ in m.e. pH

$\begin{array}{rrrrrr}0 & 0.83 & - & 0.026 & 4.6 & 9.6 \\ 60 & 0.53 & 0.30 & 0.039 & 5.2 & 8.9 \\ 120 & 0.46 & 0.37 & 0.058 & 5.8 & 7.6\end{array}$

\section{DISCUSSION}

A close study of the foregoing results clearly shows that carbonaceous material in the form of cow-pea is oxidised more quickly when added to the alkali soil in conjunction with phosphate, such as Algerian Rock Phosphates. In some blank experiments without the addition of cow-pea, it was observed that no change in $\mathrm{pH}$, available phosphate or exchangeable calcium took place even after the lapse of one year. 
The oxidation of organic matter like cowpear greatly enhances the availability of insoluble Algerian Rock Phosphates when these phosphates are added in combination with organic materials to the alkali soil. This is due to the reason that tricalcium phosphate, which is present in these Algerian rock phosphates, is converted into more soluble form of phosphates, such as dicalcium phosphate and monocalcium phosphates by the action of carbonic acid produced during the decomposition, ammonification and nitrification of added organic matter. This is clear from the following equations:-

(1) $\mathrm{Ca}_{3}\left(\mathrm{PO}_{4}\right)_{2}+\mathrm{CO}_{2}+\mathrm{H}_{2} \mathrm{O} \rightarrow \mathrm{CaHPO}_{4}+\mathrm{CaCO}_{3}$.

(2) $\mathrm{Ca}_{3}\left(\mathrm{PO}_{4}\right)_{2}+2 \mathrm{CO}_{2}+2 \mathrm{H}_{2} \mathrm{O} \rightarrow \mathrm{Ca}\left(\mathrm{HPO}_{4}\right)_{2}+2 \mathrm{CaCO}_{3}$.

The following observations of Dhar6) are of great interest in this connection :-

"The third dissociation constant of phosphoric acid is smaller than the first and second dissociations constants of carbonic acid and hence, carbonic acid converted tricalcium phosphate into dicalcium phosphate, which is more soluble than tricalcium phosphate. Thus, the availability of phosphate is increased in the soil richer in carbonic acid obtained from the oxidation of organic materials. Similarly, nitrous and nitric acids formed in the soil from ammonification and nitrification of proteins make phosphates more readily available. Thus, phosphates are more useful in the presence of organic matter like farmyard manure, straw etc. undergoing slow oxidation ".

The above experimental results are also supported by a number of workers. Jensen?) found that the addition of organic matter to a soil increases the solubility of both lime and phosphoric acid from 30-100\%. Hester and Shelton ${ }^{8)}$ have also shown that the ap-

6) N.R. Dhar, The Value of Calcium Phosphate in Atmospheric Nitrogen Fixation in Soils: Kung. Lantbruks Annaler, 21, 49-78 (1954).

7) C.A. Jensen, Effect of Decomposing Organic Matrer on the Solubility of Certain Inorganic Constituents of the Soil: J. Agri. Research, 9, 253-268 (1917).

8) J.B. Hester, and F.A. Shelton, Soil Organic Matter Investigations upon Coastal Plain Soils: Virginia Truck Expt. Sta. Bult., 94, 1397-1428 (1937). plication of suitable organic matter to the sandy truck soils of the coastal plains of U.S.A. may reduce the fixation of phosphates to an available form so that optimum yields of crop may be produced with much less superphosphate than is commonly used. Copeland and Markle') and Gerretsen ${ }^{10)}$ have also made similar observations.

The results recorded by us also clearly indicate that the exchangeable calcium of the system is greatly increased when Algerian rock phosphates are added in conjunction with cow-pea. This increase in exchangeable calcium may be ascribed to the dissolving action of carbonic acid and other weak acids, liberated by the oxidation of organic matter, on $\mathrm{CaCO}_{3}$ of the alkali soil or $\mathrm{CaCO}_{3}$ or $\mathrm{CaO}$ present in rock phosphates. In this way soluble $\mathrm{Ca}$-ions replace the $\mathrm{Na}$-ions from the exchange complex of the soil, thus, increasing the exchangeable calcium of the system. The carbon dioxide produced may also react with $\mathrm{Ca}_{3}\left(\mathrm{PO}_{4}\right)_{2}$ present in rock phosphate or calcium phosphate present in alkali soil, forming more soluble dicalcium phosphate which introduces more $\mathrm{Ca}$-ions in the system.

In all the cases, the introduction of insoluble phosphates with organic matter greatly helps in lowering the $\mathrm{pH}$ of the alkali soil. This is due to the fact that the dicalcium phosphate, formed by the decomposition of organic matter on tricalcium phosphates, When comes in contact with water, partially behaves as a dilute solution of monocalcium phosphate and can reclaim alkali soils slowly.

\section{SUMMARY}

The beneficial effect of various sparingly soluble phosphates such as Algerian rock phosphates, when mixed with organic matter

9) O.L. Copeland, and F.G. Merkle, The Infuence of Certain Soil Treatments upon the Fixation and Availability of Applied Phosphates: Soil Sci. Soc. Amer. Proc., 6, 321-327 (1942).

10) F.C. Gerretsen, The Influence of Micro-organisms on Phosphate Intake by Plants: Plant and Sutl. 1, 51-81 (1948). 
like cow-pea and added to the alkali soils, bility of phosphates increases markedly. is clear from the fall in $\mathrm{pH}$ of these alkali Hence, these alkali soils ultimately become soils. Not only the $\mathrm{pH}$ is lowered but also fertile and cultivable.

the exchangeable calcium, and, the availa- 